\title{
Fenótipo comportamental e cognitivo de crianças e adolescentes com Síndrome de Williams-Beuren******
}

\author{
Behavioral and cognitive phenotype of children and adolescents with \\ Williams-Beuren Syndrome
}

\author{
Maria Cristina Triguero Veloz Teixeira* \\ Camila Rondinelli Cobra Monteiro** \\ Renata de Lima Velloso*** \\ Chong Ae Kim**** \\ Luiz Renato Rodrigues Carreiro*****
}

\begin{abstract}
*Psicóloga. Doutora em Filosofia da Saúde pelo Centro de Ciências da Saúde da Universidade Federal de Santa Catarina. Professor Adjunto I do Programa de Pós-Graduação em Distúrbios do Desenvolvimento da Universidade Presbiteriana Mackenzie. Endereço para correspondência: R. da Consolação, 896 - Prédio 38 - Térreo São Paulo - CEP 01302-907 (cris@teixeira.org).
\end{abstract}

**Graduanda em Psicologia. Bolsista de Iniciação Científica do Curso de Psicologia da Universidade Presbiteriana Mackenzie.

***Fonoaudióloga. Doutoranda e Técnica de Laboratório Jr do Programa de Pós-Graduação em Distúrbios do Desenvolvimento da Universidade Presbiteriana Mackenzie.

****Médica. Doutora em Medicin Pediatria pela Universidade de São Paulo (USP). Livre Docente pela USP.

*****Psicólogo. Doutor em Fisiologia Humana pelo Instituto de Ciências Biomédicas da USP. Professor Adjunto I do Programa de Pós-Graduação em Distúrbios do Desenvolvimento da Universidade Presbiteriana Mackenzie.

******Trabalho Realizado no Programa de Pós-Graduação em Distúrbios do Desenvolvimento do Centro de Ciências Biológicas e da Saúde da Universidade Presbiteriana Mackenzie. Apoio Financeiro CNPq, CAPES, Mackpesquisa.

Artigo Original de Pesquisa

Artigo Submetido a Avaliação por Pares

Conflito de Interesse: não

Recebido em 26.12.2009.

Revisado em 05.05.2010; 04.08.2010.

Aceito para Publicação em 01.09.2010.

\section{Abstract}

Background: Williams-Beuren Syndrome (WBS) is a genetic disorder caused by the deletion of multiples genes of long arm of chromosome 7 (region 7q11-23), which causes behavioral and intellectual disability. For the effectiveness of educational inclusion of these children, multidisciplinary approaches are needed to guide teachers and parents. Aim: to describe the behavioral, cognitive and language profiles and to identify autistic behavior in a group of children and adolescents with WBS. Method: 10 children and adolescents with WBS, aged 5 to 16 years, and 10 children and adolescents with typical development, matched by gender and age. Instruments used for assessment were: Nonverbal Intelligence Test (LeiterR); Child Behavior Checklist (CBCL/11ㄹ-5; CBCL/6-18); Language Exam (TIPITI) and the Autism Screening Questionnaire (ASQ). Results: the group with WBS presented a greater number of behavioral changes with more inattention and social problems. Regarding the Leiter-R scale the intelligence scores were below the average for age (67.8 points) in WBS. The control group (CG) scored into the average (101.2). The group with WBS presented discrepancy in the morphosyntactic structure as well as an increased number of echolalia in the subtests of TIPITI, when compared to the CG. Conclusion: based on the behavioral and cognitive problems found in individuals with WBS, the need for a multidisciplinary follow-up focused on cognitive stimulation and behavior control is confirmed, due to the interference of these characteristics in learning abilities.

Key Words: Williams Syndrome; Intelligence; Behavior; Language.

\section{Resumo}

Tema: a Síndrome de Williams-Beuren (SWB) é uma aneusomia segmentar devido à deleção de múltiplos genes no braço longo do cromossomo 7 (região 7q11-23) associada a alterações comportamentais e cognitivas. Para que a inclusão escolar dessas crianças seja eficaz são necessárias abordagens multidisciplinares que orientem professores e pais. Objetivo: descrever o perfil comportamental, cognitivo e de linguagem e identificar comportamentos autísticos em um grupo de crianças e adolescentes com SWB. Método: 10 crianças e adolescentes com diagnóstico clínico e/ou citogenético-molecular de SWB na faixa de 5 a 16 anos, e 10 crianças e adolescentes com desenvolvimento típico, pareados por sexo e idade. Instrumentos utilizados: Teste de Inteligência Não Verbal (Leiter-R); Inventário de Comportamentos para Crianças e Adolescentes - Child Behavior Checklist (CBCL/1²-5; CBCL/6-18); Exame de Linguagem (TIPITI) e o Autism Screening Questionaire (ASQ). Resultados: o grupo com SWB demonstrou alterações comportamentais do tipo desatenção e problemas sociais em comparação com o grupo controle (GC). Na escala Leiter-R os escores de inteligência dos participantes com SWB foram abaixo da média para a idade (67,8 pontos) em comparação ao GC (101,2). O ASQ identificou um participante com comportamentos autísticos. O grupo com a síndrome apresentou defasagem na estruturação no nível morfossintático e elevado número de respostas ecolálicas nas provas do TIPITI, quando comparados ao GC. Conclusão: em função dos problemas comportamentais e cognitivos encontrados nos participantes com SWB confirmase a necessidade de um acompanhamento multidisciplinar focado na estimulação cognitiva e controle comportamental, devido à interferência destas características na escolarização.

Palavras-Chave: Síndrome de Williams; Inteligência; Comportamento; Linguagem.

Referenciar este material como:

13 Teixeira MCTV, Monteiro CRC, Velloso RL, Kim CA, Carreiro LRR. Behavioral and cognitive phenotype of children and adolescents with Williams-Beuren Syndrome 2010 jul-set;22(3):215-20. 


\section{Introduction}

The Williams-Beuren syndrome (WBS) is a segmental aneusomia due to hemizygous deletion of multiple continuous genes on the long arm of chromosome 7 (7q11.23) 1-3. Its incidence is between 1:20,000 and 1:50,000 of liveborn children 3 and its prevalence is higher than $1: 7,500$ liveborn $4 / 5$ with low familiar recurrence1.

A cognitive and behavioral phenotype of WBS is described as characterized by varying degrees of intellectual disability, deficits in visuospatial skills and executive functions (working memory and planning), specific language skills and better performance in expressive language than in the receptive, syntactic-pragmatic alterations, structural and functional linguistic limitations that vary according to the level of intellectual disability, namely the use of clichés, sound effects, intonation features, echolalia and pauses that affect communication and speech, hypersociability, enthusiasm, empathy in social relationships, generalized anxiety disorder, phobias and attention deficit disorder and hyperactivity 5-14.

Due to the necessity of inclusion of children and adolescents with WBS in regular education classrooms, assessments to assist the service of educators, families and other caregivers are necessary. The expansion of the behavioral phenotype characterization of these children is aimed. Further research is still necessary as this topic has received relatively little attention in Brazilian studies 15-18. Therefore, the current study aimed to assess indicators of cognitive and language skills in order to describe the behavioral profile and to analyze autistic behaviors in a group of children and adolescents with WBS.

\section{Method}

Ten children and adolescents with clinical and genetic diagnosis of WBS between 5 and 16 years of age and, as a control group (CG), ten children and adolescents with typical development, matched by age and gender participated in the study. The diagnosis was confirmed by a geneticist either through molecular cytogenetic examination report with confirmation of hemizygous deletion on chromosome 7(7q11.23) or through clinical report with evaluation for the syndrome. Patients were selected from the Genetics Department of the Children's Institute, Medical School, University of São Paulo (Instituto da Criança da Faculdade de Medicina da Universidade de São Paulo). The research was approved by the Ethics in Research Committee of the Presbyterian University Mackenzie (Universidade Presbiteriana Mackenzie) under CEP/UPM number 1027/02/2008 and CAAE 004.0.272.000-08. The instruments used for data collection were:

1. Leiter-R nonverbal intelligence test (Leiter International Performance Scale - Revised) 19: it assesses nonverbal intelligence skills including reasoning, visualization, memory and attention. The Leiter-R consists of 20 tests, grouped into two batteries: View/Reasoning, Attention/Memory. In this study, two tests of the battery View/Reasoning (Sequential Order and Repeated Patterns) were applied. These tests generate scores of Fluid Intelligence.

2. Brazilian version of the Autism Screening Questionnaire (ASQ) - Behavior and Social Communication Questionnaire. The ASQ is used to trace Global Developmental Disorders and/or Pervasive Developmental Disorders. It evaluates reciprocal social interaction, communication and language, and behavior alterations. The cutoff points classify individuals into three scales: no diagnosis ( $<15)$, with GDD ( $>15$ and $<22)$ and autism (> 22) 20/21.

3. The language test TIPITI evaluates the linguistic performance. The tests examine language areas in oral and written forms. Oral communication, specifically, expressive language was evaluated in the current study. For such, the following categorization, definitions and sentence completion tests were used:Categorization test: assesses the ability to organize and categorize words about daily events:

. the categorization allows the participant to organize the events in semantic areas. The following categories were used on the analyses: 1 - acceptable response and justification; 2 - acceptable response and non acceptable justification; 3- non acceptable response and justification; 4 - acceptable response without justification; 5- non acceptable response without justification; 6 - no response; 7 - only echolalia;

. definitions test: assesses metalinguistic skills, specifically the meaning that the participant attributes to the words presented. Responses were categorized as: 1- acceptable response with different attributes (higher category, function, place, synonym, association, constituent elements, content, form, material, color and size); 2 - non acceptable response; 3 - no response; 4 - only echolalia. 
. sentence completion test: assesses abilities for syntactic-semantic relations of a sentence and its respective connectives. Examines structuring skills at the morphosyntactic level from complement sentence produced by the participant. The criteria used for categorization were: 1 - correct response, 2 - incorrect response with variations (comprehended initial sentence but did not comprehend the conjunction; did not comprehend initial sentence and conjunction, comprehended but with syntax errors); 3 - no response; and 4 - only echolalia.

The response category "only echolalia" was inserted due to the high number of this type of response observed in individuals with WBS.

4. Inventory of Behaviors of Children from $1 \frac{1 / 2}{2}$ to 5 years of age - Child Behavior Checklist (CBCL/ 11/2 -5), and Inventory of Behaviors of Children and Adolescents from 6 to 18 years - Child Behavior Checklist (CBCL/6-18) were answered by parents and completed by researchers. These checklists assess skills and behavioral patterns from the past six months 23. The inventories generate different types of profiles based on their scales which are: Skills, Full Scale of emotional/behavioral problems, Scales/Syndromes of Behavioral Problems, and the DSM-Oriented Scales. Among the evaluated behavioral aspects are: skills in social and school activities, Anxious/Depressed, Somatic complaints, Social Problems, Thought Problems, Attention Problems, Withdrawn/Depression, Rule-Breaking Behavior, Aggressive Behavior, Affective Problems, Anxiety Problems, Somatic Problems, Attention Deficit and Hyperactivity Problems, Oppositional Defiant problems, Conduct problems, ObsessiveCompulsive Problems, Post-Traumatic Stress Problems, sluggish Cognitive Tempo. The raw scores were converted into weighted scores with the aid from the Assessment Data Manager 7.2 (ADM) 24.

\section{Procedures}

Data collection occurred in a single session. During the time that the cognitive and language assessment tools were applied to the child, the mother responded to the behavioral inventory. Not all scales of the inventory listed in CBCL/6-18 are contained in CBCL/1 1/2 -5. Therefore, only the scales compatible with those two instruments were included in the composed analyses.

The total number of responses to three items of TIPITI allowed us to calculate the number and percentage of accuracy. Only category 1 was considered as correct response for statistical analyses. For each group, the number of responses was grouped according to the categories established. Frequency distributions of responses of TIPITI test and weighted and raw scores of intelligence tests were calculated. Analyses of variance (ANOVA) were used to compare the test scores between the groups.

\section{Results}

The results of the Leiter-R showed an average of Fluid IQ in the group with WBS of 67.8 and of 101.2 in the CG. According to the ASQ scale, a single participant with WBS scored above 15 points, which indicates the presence of signs of Global/ Pervasive Developmental Disorder.

The results in the Categorization Test of TIPITI showed that, when compared to the CG, participants with WBS showed more responses distributed among the incorrect categories (non acceptable responses $=16$; only echolalia $=25$ ) with only a single response being categorized as correct. The CG presented 29 correct answers such for responses as for justification. Thus, a discrepancy between the groups is observed - the group with WBS clearly underperformed the GC.

On the definition task, the largest number of responses of the group with WBS focused on the category only echolalia (60 responses). In contrast, predominant responses of the CG were regarding the attributes of the association, function and superior categories (48, 39 and 29 respectively). The number of correct responses (categories: superior, function, place, synonym, association, constituent elements, content, form, material, color and size) of the group with WBS (68 responses) was significantly lower than the GC (214 responses).

In the sentence completion task, the performance of the group with WBS was also poorer than the one of CG. The WBS group presented the largest number of responses in the category "only echolalia" (92 responses), followed by 30 incorrect responses (category included comprehended initial sentence, but did not comprehend the conjunction). The WBS participants presented only a few responses in the category "correct" (Group with WBS $=10$ responses versus CG $=143$ responses). Incorrect responses of the participants with WBS presented conjunction errors (24 responses), syntactic errors (7 responses) and, with high frequency, only echolalia (92 responses).

One-way ANOVAs were applied to compare the mean of compatible scales of CBCL/11/2 -5 and CBCL/6-18 inventories between groups with WBS 
and CG. As shown in Table 1, with a 95\% confidence interval, there were statistically significant differences between groups on the following scales: sociability problems $(\mathrm{F}=14.75, \mathrm{p}<0.01)$, thought problems $(\mathrm{F}=4.75, \mathrm{p}=0.04)$, internalizing problems $(\mathrm{F} 7.57=, \mathrm{p}=0.01)$, total emotional/ behavioral problems $(F=5.23, p=0.03)$, affective problems $(\mathrm{F}=7.01, \mathrm{p}=0.01)$, anxiety problems $(\mathrm{F}=$ $7.75, \mathrm{p}=0.01)$, somatic problems $(\mathrm{F}=4.66, \mathrm{p}=0.04)$, obsessive-compulsive problems $(\mathrm{F}=11.87, \mathrm{p}<0.01)$ and problems of post-traumatic stress $(\mathrm{F}=5.58, \mathrm{p}=$ 0.03).
All the mean scores of the CG are located within the normal range. In contrast, mean scores of the WBS group represent higher scores - outside the normality range. Another ANOVA was performed to compare only the scales of the CBCL/6-18 inventory between groups (WBS group, $\mathrm{N}=8$; GC, $\mathrm{N}=8$ ). There were no differences regarding the previous ANOVA except for the scale of attention problems which showed a statistically significant difference between groups $(F=4.59, \mathrm{p}=0.04)$.

TABLE 1. Differences between the Williams-Beuren syndrome group (WBS) and the control group (CG) on compatible scales of

CBCL/1 $1 \frac{1}{2}-5$ and CBCL/6-18 inventories.

\begin{tabular}{|c|c|c|c|c|c|c|}
\hline \multirow{2}{*}{ SCALES } & \multicolumn{2}{|c|}{ WBS } & \multicolumn{2}{|c|}{ CG } & \multicolumn{2}{|c|}{ Comparison } \\
\hline & Mean & $\begin{array}{l}\text { Standard } \\
\text { Deviation }\end{array}$ & Mean & $\begin{array}{l}\text { Standard } \\
\text { Deviation }\end{array}$ & F value & $p$-value \\
\hline Competence in activities & 34,1 & 7,3 & 32,8 & 5,1 & 0,15 & 0,69 \\
\hline Social competence & 45,5 & 9.3 & 47,6 & 7,1 & 0,26 & 0,61 \\
\hline Anxiety/Depression & 63,7 & 13,8 & 54,7 & 5,2 & 4,09 & 0,06 \\
\hline Withdrawn/Depression & 64 & 9,8 & 55,3 & 5,7 & 4,55 & $0,05^{*}$ \\
\hline Somatic complaints & 57,3 & 9,9 & 51,1 & 2,8 & 4,09 & 0,06 \\
\hline Social problems & 67,7 & 10,7 & 52,3 & 3,4 & 14,75 & $<0,01^{*}$ \\
\hline Thought problems & 63,3 & 8,6 & 54,3 & 7,8 & 4,75 & $0,04 *$ \\
\hline Attention problems & 65,7 & 8,5 & 57,7 & 8,5 & 3,43 & 0,08 \\
\hline Rule-Breaking Behavior & 57 & 8,6 & 56,6 & 7,6 & 0 & 0,92 \\
\hline Aggressive behavior & 57,9 & 7 & 55,3 & 6,6 & 0,6 & 0,44 \\
\hline Internalization problems & 60,9 & 11,3 & 49,6 & 9,5 & 7,57 & $0,01^{*}$ \\
\hline Externalization problems & 56,1 & 9,8 & 52,3 & 11,2 & 0,34 & 0,56 \\
\hline Total problems & 61,7 & 9,7 & 50,5 & 11,7 & 5,23 & $0,03^{*}$ \\
\hline Affective problems & 62 & 10,5 & 53,5 & 4,3 & 7,01 & $0,01^{*}$ \\
\hline Anxiety problems & 64,6 & 8,3 & 56,4 & 6,7 & 7,75 & $0,01^{*}$ \\
\hline Somatic problems & 57,3 & 8,4 & 50,7 & 2,1 & 4,66 & $0,04^{*}$ \\
\hline $\begin{array}{r}\text { Attention deficit and hyperactivity } \\
\text { problems }\end{array}$ & 61,8 & 9,6 & 57,4 & 9,9 & 0,75 & 0,39 \\
\hline Oppositional defiant problems & 57,7 & 7,2 & 56,4 & 7,5 & 0,19 & 0,66 \\
\hline Conduct problems & 54,5 & 7,7 & 55,1 & 7,6 & 0,02 & 0,87 \\
\hline Obsessive-compulsive problems & 63,2 & 10 & 50,8 & 1,7 & 11,87 & $<0,01^{*}$ \\
\hline Post-traumatic stress problems & 64,6 & 9,4 & 55,6 & 5,2 & 5,58 & $0,03^{*}$ \\
\hline
\end{tabular}




\section{Discussion}

The TIPITI results show significant difficulties of participants with WBS in establishing syntacticsemantic relations and using conjunctions as well as deficits in the abilities to structure sentences at the morphosyntactic level and a high frequency of echolalic responses. High scores on the scale of social problems of CBCL/6-18 were observed for items: communication problems, jealousy in social relationships, and preferences for younger partners with an average of 67.7 (see Table 1). However, the group with WBS did not differ from $C G(F=0.26$, $p=$ 0.61) on the scale assessing the number of social interactions (indicator of sociability). This shows that these children and adolescents maintain adequate levels of sociability despite language difficulties.

As shown in previous studies, receptive language skills are more impaired than expressive skills in individuals with WBS 25. These limitations, as observed in the current study, could compromise not only the socialization process but also the educational process. On one hand, according to findings of TIPITI, they showed prolix speech with characteristics that may lead teachers to evaluate their communication skills as appropriate. On the other hand, during the educational process, most of these deficits will probably interfere with learning, for example, making it difficult to comprehend tasks, instructions, rules and other demands related to the educational process 5, 12 .

The alterations observed in the behavior of participants with WBS (measured by the CBCL) added to the intellectual disability (measured by the intelligence test) should be carefully observed in the educational context as they may interfere in the overall learning process. Often, teachers may be unaware of these characteristics and may not be able to implement appropriate strategies to enable inclusion and effective learning of these children.

On the social problems scale of CBCL/6-18, the scores of participants with WBS were high, demonstrating that they do have relationship problems. However, on the social competence scale (which measures the frequency of social interactions), the scores indicate normality. However, the quality of those interactions must be carefully analyzed. These findings are consistent with previous studies 4-6, 8 / 9, 26. Other variables that may contribute to the scale of social problems are behavioral alterations such as anxiety, depression and attention problems. It is noteworthy that scores on such variables were higher in the group with WBS when compared with the GC. Such findings are also in agreement with others studies 3,5/6,26/27.
Finally, one important finding is that, in the WBS group, one participant showed behavior characteristics indicative of alterations of the autistic spectrum although the literature has shown that the two disorders, in general, present distinct social and clinically opposite phenotypes regarding one of the cardinal symptoms of autism spectrum disorders: problems of social interaction 14, 28. The data are in agreement with previous studies 29. In the specific case of this child, further evaluation for confirmation or otherwise of Autism Spectrum Disorder is recommended.

\section{Conclusion}

The study presented preliminary data for indicators of cognitive and behavioral phenotype of children and adolescents with WBS. This is a study with a limited sample size and, therefore, one should be careful when extending these results to the population. However, the current study has social and scientific relevance for allowing the expansion of this knowledge, especially from the behavioral standpoint 30 of Brazilian children and adolescents with WBS. The findings presented here aid on the understanding of this population and on the source of their learning difficulties.

Individuals with WBS have an increased capacity of communication and sociability, but these skills may mask their cognitive deficits. They still have difficulties to establish proper communication, present a repertoire of limited vocabulary and with excessive use of clichés, stereotyped sentences and imitation behaviors that affect the quality of the relationships they establish with other people. Alterations as anxiety, depression and attention problems are also highlighted which, when combined, may bring difficulties in the educational context.

There is the need for a multidisciplinary follow up of children and adolescents with WBS. Such follow up should be redoubled at school age due to the commitment that many of these characteristics produce in learning skills. Teachers, educators and other professionals connected to regular education should have access to this information as a way to assist the management of children and adolescents with WBS. Therefore, proper assessment of these children aiming to aid these professionals on a better and more appropriate service as well as intervention programs aiming to improve these difficulties and the quality of life of children and adolescents with WBS would be indicated. Indeed, future studies on a more comprehensive behavioral and cognitive assessment as well as studies on pedagogical methods appropriate for this population should be carried out in regular classrooms in order to contribute to a more effective teaching and, consequently, learning process. 


\section{References}

1. Rossi NF, Moretti-Ferreira D, Giacheti CM. Genética e linguagem na Síndrome de Williams-Beuren: uma condição neuro-cognitiva peculiar. Pró-Fono. 2006 setdez;18(3):331-8.

2. Deutsch SI, Rosse RB, Schwartz BL. Williams Syndrome: A Genetic Deletion Disorder Presenting Clues to the Biology of Sociability and Clinical Challenges of Hypersociability. CNS Spectr. 2007 dez;12(12):903-7.

3. Sugayama SMM, Leone C, Chauffainlle MLLF, Okay TC, Kim CA. Síndrome de Williams: proposta de sistema de pontuação para diagnóstico clínico. Clinics. 2007;62(2):159-66.

4. Meyer-Lindenberg GA, Mervis CB, Berman KF. Neural mechanisms in Williams syndrome: a unique window to genetic influences on cognition and behaviour. Nat Rev Neurosci. 2006 mai;7(5):380-93.

5. Rossi NF, Moretti-Ferreira D, Giacheti CM. Perfil comunicativo de indivíduos com a Síndrome de WilliamsBeuren. Rev. Soc. Bras. Fonoaudiol. 2007 jan-mar;12(1):0109.

6. Artigas-Pallarés J. Fenotipos conductuales. Rev. Neurol. 2002;34(1):38-48.

7. Leyfer OT, Woodruff-Borden J, Klein-Tasman BJ, Fricke JS, Mervis CB. Prevalence of psychiatric disorders in 4 to 16-year-olds with Williams syndrome. Am J Med Genet B Neuropsychiatr Genet. 2006 set 5;141B(6):615-22.

8. Martens MA, Wilson SJ, Reutens DC. Research Review: Williams syndrome: a critical review of the cognitive, behavioral, and neuroanatomical phenotype. J Child Psychol Psychiatry. 2008;49(6):576-608.

9. Järvinen-Pasley A, Bellugi U, Reilly J, Mills DL, Galaburda A, Reiss AL, et al.Defining the social phenotype in Williams syndrome: A model for linking gene, the brain, and behavior. Dev Psychopathol. 2008;20(1):1-35.

10. Aravena T, Castillo S, Carrasco X, Mena I, López J, Rojas JP, et al. Williams syndrome: clinical, cytogenetical, neurophysiological and neuroanatomic study. Rev Med Chil. 2002 jun;130(6):631-7.

11. Cardoso-Martins C, Silva JR. A relação entre o processamento fonológico e a habilidade de leitura: Evidência da síndrome de Down e da síndrome de Williams. Psicol. reflex. Crit. 2008;21(1):151-9.

12. Rossi NF, Souza DH, Moretti-Ferreira D, Giacheti CM. Perfil da fluência da fala na síndrome de Williams-Beuren: estudo preliminar. Pró-fono. 2009 abr-jun;21(2):107-12.

13. Joyce CA, Zorich B, Pike SJ, Barber JC, Dennis NR. Williams-Beuren syndrome: phenotypic variability and deletions of chromosomes 7, 11, and 22 in a series of 52 patients. J Med Genet. 1996 dez;33(12):986-92.

14. Farran EK, Jarrold C. Visuospatial Cognition in Williams Syndrome: Reviewing and Accounting for the Strengths and Weaknesses in Performance. Developmental neuropsychology. 2003;23(1\&2):173-200.

15. Brasil. Ministério da Educação. Secretaria de Educação Especial. Decreto Nº 5.296 de 02 de dezembro de 2004.
16. O'Reilly MF, Lancioni GE, Treating food refusal in a child with Williams syndrome using the parent as therapist in the home setting. Journal of intellectual disability research: JIDR 2001;45(Pt 1):41-6.

17. Fidler DJ, Philofsky A, Hepburn SL. Language phenotypes and intervention planning: bridging research and practice. Ment Retard Dev Disabil Res Ver. 2007;13(1):47-57.

18. Midro AT, Olchowik B, Lebiedzinska A, Midro H. To know more about the Prader-Willi syndrome. Multidisciplinary support. Psychiatria Polska, 2009;43(2):151-66.

19. Roid GH, Miller LJ. Leiter International Performance Scale--Revised. Wood Dale, IL: Stoelting. [Test battery, Manual, and computer scoring software]; 1997.

20. Berument S, Rutter M, Lord C, Pickles A, Bailey A. The autism screening questionnaire: diagnostic validity. $\mathrm{Br}$ J Psychiatry. 1999 Nov(175):444-51.

21. Sato FP, Paula CS, Lowenthal R, Nakano EY, Brunoni $\mathrm{D}$, Schwartzman JS, et al . Instrument to screen cases of pervasive developmental disorder: a preliminary indication of validity. Rev. Bras. Psiquiatr. 2009 mar;31(1):30-3.

22. Braz HA, Pellicciotti THF. Exame de linguagem Tipiti. São Paulo: MNJ LTDA; 1988.

23. Achenbach TM. Manual for the Adult Behavior Checklist/18-59 and 1991 profile. Burlington: University of Vermont Department of Psychiatry; 2001.

24. Achenbach TM, Rescorla LA. Manual for the ASEBA School-Age Forms \& Profiles. Burlington: University of Vermont, Research Center for Children, Youth \& Families; 2001.

25. Volterra V, Caselli MC, Capirci O, Tonucci F, Vicari S. Early linguistic abilities of italian children with Williams syndrome. Dev Neuropsychol. 2003;23(1-2):33-58.

26. Fisch GS, Carpenter N, Howard-Peebles PN, Holden JJ, Tarleton J, Simensen R, et al. Studies of age-correlated features of cognitive-behavioral development in children and adolescents with genetic disorders. Am J Med Genet A. 2007;143A(20):2478-89.

27. Jauregi J, Arias C, Vegas O, Alen F, Martinez S, Copet P, et al. A neuropsychological assessment of frontal cognitive functions in Prader-Willi syndrome. J Intell Disabil Res. 2007 mai;51(Pt.5):350-65i.

28. Riby DM, Hancock PJ. Do Faces Capture the Attention of Individuals with Williams Syndrome or Autism? Evidence from Tracking Eye Movements. J Autism Dev Disord. 2009 mar;39(3):421-31.

29. Klein-Tasman BP, Mervis CB, Lord C, Phillips KD. Socio-communicative deficits in young children with Williams syndrome: performance on the Autism Diagnostic Observation Schedule. Child Neuropsychol. 2007 set;13(5):444-67.

30. García-Nonell C, Rigau-Ratera E, Artigas-Pallarés J, García-Sánchez C, Estévez-González A. Síndrome de Williams: memoria, funciones visuoespaciales y funciones visuoconstructivas. Rev Neurol. 2003;37(9):828-30. 